\title{
EU CHILDREN IN BREXIT BRITAIN: RE-NEGOTIATING BELONGING IN NATIONALIST TIMES
}

\author{
Dr Elisabetta Zontini and Dr Davide Pero' \\ University of Nottingham \\ Published in International Migration in April 2019
}

\begin{abstract}
This article contributes to debates on identification, home and belonging by focusing on $E^{i}$ children in Brexit times. It does so by combining attention to the emotional and affective side of integration with a focus on the effects of the discursive practices of the state on these processes. The article explores how Italian children and their parents navigate the increasingly neo-assimilationist pressures in Britain. Specifically, it looks at children's ways of accommodating their parents' values of mobility, multilingualism and transnationalism with the revived nationalist logic now dominant. The article argues for renewed scrutiny into the role of public discourses on migrants' experiences, which illuminate the redrawing of the boundaries between inclusion and exclusion at moments of crisis.
\end{abstract}

\section{INTRODUCTION}

One morning in April 2016 in the build-up period to the Brexit referendum Claudio, a 9year-old boy born to two Italian parents in the UK, was having breakfast while the BBC Radio 4 Today programme discussed Brexit and immigration. Suddenly, he asked his parents:

C: Can I have an English passport?

M: Why?

$\mathrm{C}$ : Because I want to be English

M: Can't you just be English without a passport?

C: No

M: Why do you need an English passport? 
C: Because it says English. If I have an Italian passport does it mean that I'm Italian?

M: Can't you just say that you are English if you feel that you are English?

C: No

The next day his brother Paolo, then aged 11 and also born in the UK was in the kitchen while the same radio programme was on, discussing the same topic. He asked his mother:

P: Are you doing the citizenship thing?

M: Yes we are

P: What about me? Do I have an Italian passport?

M: Yes

P: Will I get a British one?

M: Yes

P: Can you please don't do it for me?

M: Why?

P: Because then it will mean that I'm more British.

M: No, it doesn't mean that, you are the same person. If you feel Italian, can't you say that you are Italian?

P: No. If I say I feel Japanese, does that make me Japanese?

As these anecdotes illustrate, these brothers were reacting very differently to the same Eurosceptic and anti-migration discourse, played out by the mainstream media, one trying to assimilate claiming an English identity and one rejecting assimilation altogether aligning with his parents' national identity. This article explores the processes of identification and belonging of children of EU parents, like Claudio and Paolo, who are growing up in the UK in a moment of crisis underpinned by renewed nationalism, Euroscepticism and "Brexit". In several European countries and the USA, a broader discontent with globalization is going hand in hand with the progressive rejection of cosmopolitan values and mobile lifestyles. How do children of EU parents respond to their public portrayal as unwanted outsiders beyond the boundaries of what it means to be British? What are their experiences at a time when the values of cosmopolitanism and cultural pluralism that they embody are being questioned? 
In the UK this exclusionary trend is encapsulated well by Prime Minister Theresa May's statement: "If you believe you are a citizen of the world, you are a citizen from nowhere" (2016). This statement highlights the changed interplay between mobility and fixity, a new axis of difference that has increasingly been shaping recent political discourses in Western countries. Faist (2013: 1643) highlighted the significance of the discursive representation of mobility, inviting scholars "to look at the social mechanism by which movement is legitimised or de-legitimised". An expanding body of literature demonstrates how migrants and minorities in Britain are increasingly othered, especially if Muslim (Kundnani 2007, Modood 2012) but also Eastern European (Fox et al. 2012).

We aim to contribute to this debate by focusing on how this exclusionary othering has been extended to groups regarded as less disadvantaged, being white, educated and middle class. We are interested in the intensification of these processes of othering and their extension beyond the reification of difference based on religion, race and class. Taking the case of Britain, we show how mobility, cosmopolitanism and multiple identifications are currently being actively devalued and constructed as dangerous, impacting migrants and their children.

Theoretically we combine a perspective on migrants' settlement and integration that pays attention to the emotional and affective side of these processes (Boccagni and Baldassar 2015, Svašek 2008, 2010), with our longstanding concern with the effects of receiving societies' cultural politics of identity and difference (Però 2013). We do so by exploring how the current discursive practices of the state influence how migrants and their children feel in the UK. The article thus examines the consequences of Brexit not so much from a legal and practical perspective (e.g. in relation to rights to settlement, family reunification, health and education, see Kilkey 2017, D'Angelo and Kofman 2018), but in terms of how this changed cultural-political context is impacting EU children's sense of identity and belonging to the country where they grew up.

The following section highlights the key characteristics of South to North intraEuropean migration from the 1990s to the present, focusing in particular on Italians. 
Next, we review debates on identification, home and belonging, highlighting the importance of structural and discursive contexts underpinning these processes. Then we discuss our methodological approach. Finally, two sections present our findings: first, on processes of transnational emplacement of EU children and their families, and then on their negotiations of home, identity and belonging.

\section{CONTEXTUALIZING FREE MOVERS IN BREXIT BRITAIN}

Since the 1990s Britain has been a favorite destination of intra-European mobility with large numbers of EU professionals and graduates choosing the UK. Favell (2008) has termed such migrants "Eurostars": students and professionals taking advantage of free movement within Europe to pursue career opportunities and self-realization. What these migrants have in common is their desire to enjoy the "denationalizing" freedoms that EU mobility entails, thus valuing flexibility, multilingualism and cosmopolitanism (Favell 2008, Marcu 2014, Recchi 2015).

Southern Europeans, and Italians in particular, have constituted an important component of this migration. The flow of Italian graduates to countries like the UK has been a key feature of Italian emigration since the early 1990s (D'Angelo and Kofman 2016), with 600,000 Italians estimated to live in the UK in 2016 (Marchese 2016). These migrants moved to the UK during what Barbulescu (2016) has called the "golden era" of freedom of movement, a time when moving across Europe was like "migrating in first class" with few of the obstacles that international migration normally entails (Recchi 2015). These pioneers of freedom of movement were followed from 2008 by "posteconomic crisis migrants". Despite their larger numbers and somewhat different push factors, they shared many characteristics with their predecessors, being on the whole urban, middle class and highly skilled (D'Angelo and Kofman 2018, Dubucs et al. 2017). Contrary to Eastern European migrants who have experienced restrictions to their mobility both before and after the EU enlargement (Fox et al. 2015) and who, despite their high level of education, have witnessed widespread deskilling, Italians have been socialized to perceive Europe as a continent of free mobility and their status and identity as citizens of the European Union. They have also obtained jobs matching their qualifications often allowing them to fulfill their career aspirations (Recchi 2015). 
While such position and rights were taken for granted, a process of nationalist retrenchment began during the economic crisis in the UK and other Northern EU countries that were net recipients of migrants from other member states (Lafleur and Mescoli 2018). According to Barbulescu (2016), these countries gradually started to hollow out freedom of movement rights; for instance, by introducing measures to limit access to social benefits, and by deporting homeless EU citizens. This has been documented in the UK with respect to Check and Slovak migrants who have been subjected to several instances of welfare 'cancellation' and widespread and prolonged arbitrary retention of documents (Guma and Jones 2018). Progressively, also the mobility of EU citizens from older member states has started to become contested. In Belgium, Italians claiming benefits are increasingly being deprived of their residency permit as well as being subjected to intimidations in bureaucratic interactions aimed at inducing their voluntary departure (Lafleur and Mescoli 2018).

Increaingly freedom of movement has become a contested aspect of the European project, culminating, in the UK, with the Brexit referendum of June 2016. Two years on from the referendum, the legal status of EU nationals in the UK remains unclear (D'Angelo and Kofman 2016). Simultaneously, in public discourse EU nationals have been demoted from "EU citizens" to (unwelcome) "migrant workers" (D'Angelo and Kofman 2018, Guma and Jones 2018, Lafleur and Mescoli 2018, Ranta et al 2018).

\section{HOME, IDENTITY AND BELONGING BETWEEN ROOTEDNESS AND TRANSNATIONALISM}

Favell (2008) had described EU free-movers as functionally well-integrated into the cities where they live without being as integrated in the "national culture" around them (see also Recchi 2015). Others have portrayed them as "liquid", or flexible, temporary, 
individualized and following unpredictable forms of legal mobility (Engbersen and Snel 2013). They have also been described as highly transnational, developing deterritorialized family units where presence/absence and spatial proximity/distance are normalized (Zontini and Reynolds 2018). Identity construction for such transnational subjects has been influenced by possibilities and constraints within more than one national context (Reynolds and Zontini 2016). This is particularly the case for children and young people growing up in migrancy (Seeberg and Gozdziak 2016), who develop complex affective links that challenge the relationship between citizenship, identities and belonging (van Liempt 2011). Trasnational mobility has also be shown to foster cosmopolitan values and a European identification (Recchi 2105).

In the migration literature such transnational links have been described positively for both migrants and their children (Haikkola 2011, Moskal 2014, Zontini and Reynolds 2018). These positive accounts, however, are in sharp contrast to the public discourse where the backlash against multiculturalism constructs them as clashing with integration, threatening social cohesion (Vertovec and Wessendorf 2010). Ghorashi (2017: 2438), writing about the Dutch context, talks about the paradox of our era defined by fluidity and mobility and a current dominant discourses on identity and belonging where “'rootedness' in a culture or a geographic territory is considered a natural and normal feature of humanity".

Studies conducted in the UK have shown that processes of racialization and othering have not exempted white migrants both before and after Brexit. As Fox et al argue (2012) racialization does not necessitate phenotypical or biological differences as processes of differentiation can also be made on the basis of cultural traits (such as language and religion). This is evident in the discrimination received by Easter European migrants on the basis of allegedly being potential 'welfare tourists' or speaking a foreign language (Morosanu and Fox 2013, Fox 2015), Rzepnikowska (2019) argues that visible and audible markers of difference can be seized upon in exclusionary ways and "the privilege of whiteness disappears when they start speaking" (2019:70). 
An essentializing rootedness discourse was evident in the Brexit Leave Campaign, which was based on a "narrative of retreating from a globalizing world that is no longer recognizably British" (Virdee and McGeever 2017: 1803). This narrative is well exemplified by Goodhart (2017) who contrasts those who come from "Somewhere" to those who could come from "Anywhere". The former are described as being rooted in a specific place or community, like a small town or the countryside, socially conservative and not highly educated. The latter are the footloose, often urban and university-educated individuals with less attachment to place and national identities. Goodhart suggests that the Somewheres need to be protected against the Anywheres, whom he sees as hegemonic and oppressive.

In contrast, we argue that free-movers do not come from "nowhere", as Goodhart claims; they too often come from the same type of socially conservative places that characterize Goodhart's Somewheres. As Favell (2008) has argued, they often migrated to escape those constraining conservative environments and fulfil their cosmopolitan and progressive ideals in what they saw as more liberal and multicultural societies. Contrary to Goodhart's simplistic portrayal of them as lacking any ties and attachments, freemovers typically have stayed quite connected to their places of origin with which they maintain strong transnational connections, while at the same time re-rooting in the sites of emplacement. Moreover, the kind of "liquid migration" which seems to concern both the public and policy-makers, might apply only to young EU migrants (Lulle et al. 2018). In fact, as both Favell (2008) and Ryan and Mulhooland (2014) conclude, a "supermobile" lifestyle might only be possible at particular stages of one's life course. After a while emplacement (associated with childbirth) - or what Bygnes and Erdal (2017) have described a "grounded life" - becomes a necessity. However, little research considers the characteristics of "grounded life" which also accounts for the impact of Brexit. When talking about Brexit, the focus is often on individuals as liquid migrants who could easily relocate somewhere else or return "home". Kofman (2017) argues that this is not the case as migrants' spouses; older relatives and children (often UK-born) will also be affected in complex ways (Kilkey 2017).

We argue that more attention needs to be paid to the policy and discursive context 
in order to understand young people's identity and belonging (Reynolds and Zontini 2016) and incorporation more generally (Però 2013). Here we want to analytically describe what happens when such a context becomes more hostile, drawing on new studies on emotions and migration that have problematized the straight-line trajectory that sees identity and belonging as moving over time from a home to a host country orientation (Boccagni and Baldassar 2015, Zontini 2015). Such studies argue instead that "in a world of mobility, personal attachments to people and places are multiple and changing" (Svašek 2010: 877). Such emotional attachment and belonging can be activated by memory, imagination, long-distance communication and return visits (Svašek 2008) but also by structural constraints, such as immigration policies (Svašek 2010) and, as pointed out in this article, public discourse, an aspect that we believe requires further investigation, especially at times of crisis (see Miller 2018).

\section{METHODOLOGY}

This study is the result of two years of ethnographic work with a selected number of EU families. These families were chosen purposefully and initially accessed through personal contacts and subsequently through snowballing. We recruited families with children aged from seven to 17 with at least one Italian parent, thus belonging to the more privileged group of the "old" EU migrants (Lulle et al., 2018) and residing in the Midlands region. This was to focus on established resident families, i.e. those who had been in the UK for at least 10 years, and who lived outside of the more researched cosmopolitan London region (Lulle et al. 2018). This is also an area that voted predominately Leave in the referendum.

The research developed into a longitudinal ethnographic project. The first interviews and observations started in spring 2015, at the time when the Conservative government was introducing the legal provisions for the referendum and Brexit seemed to many an unlikely outcome. The research continued up to the referendum itself and its aftermath. It encompassed a number of methods including observations inside and 
outside the homes; participation in social as well as political gatherings (e.g. the "Unite for Europe March" in 2016); informal conversations with the parents both in person and on-line (through a Whatsapp group); art work with the children; and semi-structured interviews with the children and their parents.

In terms of artwork, we offered a number of creative activities that children could choose to conduct prior to and/or instead of an interview (as suggested by methodological literature on working with children; Weller 2012). These activities (which included drawing flags and imaginary passports) revealed some of their perspectives and prompted themes for interview discussion. Teenagers, however, often opted for the standard interview format and had much to say about the topics in question. We interviewed 14 children aged from seven to 17 (seven boys and seven girls) and five parents (all mothers). Of these, seven children were interviewed after Brexit and four of those interviewed before were interviewed again afterwards to see if anything had changed. All interviews were conducted by the first author either in Italian or English, with the interviewees choosing the language to be used, and were transcribed in full in the original language (seven children chose Italian and seven English). Participant observations were conducted by both authors and discussed in detail. Thematic analysis of the material collected (interview transcripts, field diaries, artwork) was also conducted jointly. Overall, the strength of this study lies in its in-depth interpretative nature grounded in a variety of complementary methods. It also lies in its longitudinal dimension, which has allowed to observe the consequences of Brexit both as a process (a particular climate developing well before the referendum) as well as a moment of crisis triggered by the referendum itself.

\section{PROCESSES OF TRANSNATIONAL EMPLACEMENT AMONG EU FAMILIES}

The settlement experiences of the EU families emerged as rather similar to each other and we would describe them as "transnational emplacement". This is a form of integration characterized by the simultaneous development of strong local connections and 
emplacement practices with the retention of an ongoing engagement with the migrants' areas of origin, particularly through dense family connections. Dubucs et al. (2017) found Italians engaged in similar 'balancing acts' between local and transnational attachements in Paris. In our case-study, this was characterized by a growing recognition by the freemover parents that settlement had become a reality and further mobility was unlikely (although a possibility), coupled with the maintenance of very strong transnational practices. These emplacement practices included buying properties, sending children to local schools and reluctantly moving medical and dental treatment to Britain. The latest practices included the acquisition of settlement rights through permanent residency and subsequently naturalization aiming to mitigate the insecurities promted by Brexit. This echoes the "undeliberate determinacy" purseud by Polish migrants (McGhee et al. 2017). These practices, however, divides our participants and are much debated at every social gathering. At the time of writing, eight parents had initiated these processes: one was not yet entitled to apply, three were strongly against doing so (because if their conditions worsened for not having these papers, then the UK was considered not worth living in) and the rest had not yet done it due to time constraints (the procedures are very timeconsuming as well as costly) and were hoping that a political, rather than an individual, solution was going to be found. All expressed emotional stress and anxiety as a result of these processes.

For instance, once Brexit was announced, Katrina felt compelled to quickly apply for permanent residency to restore some sense of security. The process was long and complicated and also put at risk her ability to be mobile at a time when her ageing father might have needed her care. The process took a toll on her and discouraged her subsequent application for citizenship.

I remember I started having panic attacks and a fundamental sense of loss of security. I tried to wait until it settles and started to get the German ID cards so we could apply for residency, because one still had to send in the passports and, even when they made it easier from October, they didn't do that for children so one still had to send the original cards. (...) My father had a stroke, so we can't just give up our passports for six months so we had to first go and get these. Then we applied, which took me quite some time at the beginning of a very busy semester, 
(...) In the meantime I can see my kids are pushing for UK passports but I am not in the emotional headspace right now to go again.

Further, Brexit is starting to change some emplacement practices. We thus concur with McGhee's et al.'s (2017) observation that civic integration practices do not necessarily signal an intention to settle permanently. While trying to secure their settlement by consolidating their legal rights, families are simultaneously changing their outlook on the future. This is particularly evident in their home-making practices, with one participant commenting that they are not going to refurbish their house as they had planned, because they now think they might leave. Another changed her plans to buy a house in the UK as "we don't know what will happen". Most of the mothers committed themselves to short-term plans to stay in the UK only until their teenage children reached university. After that they considered "returning home" as a possibility, even if that would disrupt their current career and they were far from retirement age. In Franca's words,

The only thought that makes me feel better is that my daughter is four years away from university; once she is gone to university, I will be free, maybe not immediately because I'll have to support her financially, but after two, three years, I will be free to take even drastic decisions with my job. I could go nearer or spend much more time with my mother (in Italy).

Lucia too said, "if it wasn't for [her son] Fabrizio I would have already left”.

These narratives demonstrate that the sense of home has been unsettled by Brexit (Miller 2018) suddenly substituted by a sense of disembedding (Ryan 2017) and displacement. Martina summarizes this well when recapping her experience of more than 20 years in the UK:

enthusiasm, acceptance, efforts at integrating, feeling integrated, beginning of having doubts, desire to return to Italy, now disappointment of having done the wrong thing, not knowing what to do basically... 
All the mothers described Brexit as a "rupture" (Lulle et al. 2018). Franca recalls the moment when she realised that things had changed for her and her family:

For me something changed. When I've heard on the radio that they were talking about making those lists of foreign employees in various companies...I still remember it, I was in the car and I froze when I've heard it, because things took an almost Nazi tone, I didn't like it.

Katrina described Brexit thus:

It is a game changer and I think people who have not gone through anything similar will have a very hard time understanding, even if they have empathy, to actually imagine what it's like, especially when you have children...

Evidently, EU parents have become very concerned for the negative impact that their foreign status can have on their children. It is to these children's experiences that we now turn.

TRANSNATIONAL CHILDREN NEGOTIATING HOME, IDENTITY AND BELONGING

The opening vignette presented two brothers' different reactions to an either/or neonationalist discourse: an exclusionary discourse that precludes possibilities for multiple and supra-national identifications (at once being European, British and Italian), pushing the children of EU migrants to become fully British through assimilation or to link their identity and belonging automatically to the place of origin of their parents (Ghorashi 2017). Below we examine some of the strategies of belonging that other children adopted in navigating the "either/or" discourse.

Navigating the either/or discourse 
National thought frames are ingrained in people's self-conception (Pratsinakis 2018, see also Billig 1995). This was evident in how the children saw themselves and others, as they rarely claimed dual or hybrid identities. As Camilla explained when we asked her if she felt British-Italian:

You can either go on where you were raised or where you feel attached to and where your parents are from. When people ask me, "ooh are you Italian or are you English?" I say "Italian". Straight away, obviously even if I was born here and I was raised here I always think I am Italian, full on Italian. I don't classify myself as British or anything else, I'd always pick being Italian over English (Camilla $13)$.

Asked if she ever says both: "No, no, I never say both. I say one or the other". Like Camilla, when confronted by the either/or discourse, many of our participants "picked" being Italian over English.

I would say that I'm Italian because both my parents are Italian, everybody tells me "ah you are Italian" and all my family lives in Italy so yes I would say that I'm Italian (Silvia 12).

When we ask Anna (who has an English father and an Italian mother) about her national identity, she replies: "Italian, definitely, there is no question about that" (Anna, 14).

Some children, like Silvia, seem to have internalised the rootedness discourse, the idea that one naturally belongs to the place of his/her origin, via the parents (Ghorashi, 2017). For others, like Anna, claiming "Italianness" seems a reaction against the push to assimilate.

If someone asks you where are you from, if you say that you are Italian is more interesting than saying that you are English, because English people think they are the best, but they suck (Anna, 14). 
When we asked Camilla how she thought other people saw her, she hesitated. Interestingly, for someone who was born and lived all her life in the UK, she does not think people see her as British.

Italian people think of me as Italian and English people think of me as ..., I don't know actually, I think some think of me as Italian, half and half and some people think of me as English just because... I don't really think that they think of me as British. They think of me half and half or just Italian, but Italian people don't, oh actually I think it is the same. I'm not really sure about that question; I will have to ask them (Camilla, 13).

Four of the boys in our sample "picked" being British. However, despite the push in post-multicultural Britain for newcomers to assimilate, their efforts are often not recognized by the majority population. Bob (15), who has a German mother and an Italian father explained:

I see myself as someone who lives in England and is English and speaks two other languages and has two parents from other places, but I am British pretty much, though to other people I'm not, I'm like the German one or whatever.

The reason why he thinks that he is not seen as British by other people is his (very light) accent. Barely noticeable after living in the UK for many years, accent is used by others a "marker of difference" to locate him as unequivocally foreigner.

Given the hegemonic power of ideologies of national belonging (Pratsinakis 2018), claiming dual or hybrid identities was always difficult for these children. Brexit, however, with its renewed emphasis on allegiance to the nation, has made the possibilities of multiple belonging even harder.

Living two parallel lives 
Trying to belong to both family (perceived as Italian) and school and friends, many of the children adopted a similar strategy, which they called "living two parallel lives". Silvia explained:

When I go back home I get like a "switch" [said in English] and I become more Italian.

For her, school is an English environment and home an Italian one. The two are not mixed and she does not like it when she is reminded about being Italian at school. She does not feel British-Italian but British and Italian in two different spaces.

It is like if it was two different lives - when I talk in Italian with my Italian family I'm Italian, when I talk in English with my English friends I'm English! Therefore there are two different lives.

Sara, a 17-year-old girl with two Italian parents, made a similar point.

I have two worlds that do not mix, that they have never mixed and, honestly, it's bad to say but I don't want them to mix. I don't want English people arriving in my Italian world, I don't like that, I really don't like that. My English boyfriend wanted to visit me in Italy and I said no. Not because I didn't want him but because nobody has to touch my Italy! (Sara 17)

Anna (14) went as far as calling it the "double life of Jekyll and Hyde". Like Sara, for her this double life is positive.

I don't mind having these two lives, as having just one would be a bit boring. When I'm among Italian people I am Italian, and when I am among English ones I'm English.

When we asked her if it is difficult to switch from one to the other, she replied negatively.

The children described in positive terms their ability to switch effortlessly between two lives. It is clear that whiteness allowed them that possibility. However, according to the narratives of both parents and children, Brexit has hardened the necessity of keeping these two lives (and their languages) separated, making the children's daily 
negotiations described above more difficult. Camilla, for instance, reflected on the impact of Brexit on her life.

After Brexit many things have changed, my opinions have changed. I know that people... I can't be as open. I feel like I can't be open with being Italian any more. If I have a phone call I'll speak English because I don't want people to judge me as much, I don't want that pressure from the people. I know that they voted me to leave, they are trying to push me away, so I try and be as English as possible (Camilla, 13).

Feeling uncomfortable, or even scared, in speaking one's language is remarkably similar to Polish adult migrants experiences in Guma and Jones's (2018) study.

Beyond the either/or discourse?

Not all children accepted the "either/or discourse". One 10 year-old boy was comfortable expressing a dual national identity (his father is English, his mother Italian) when we interviewed him in 2015:

I feel half Italian and half English. I like speaking two languages and I like both countries equally. (...) I support two football teams, one English, the same as my dad, one Italian, the same as my uncle (Fabrizio, 10).

He was the only one in our sample to openly express a dual identification. Brexit, however, has seriously impacted on his sense of belonging. After crying inconsolably on the morning after the referendum, he has decided to reject Britishness to the point that at the end of the school year he refused to sing the national anthem in a school performance. When asked about the reason for his refusal by the head teacher, he replied that he was not going to sing the national anthem of the country that wishes to kick his mother out. He says that now he is more proud of being Italian, specifically because of Brexit.

I now feel more European and Italian. I think that all us Europeans in the UK we have to stay united and fight Brexit. 
Fabrizio's sense of security in his own country has been shaken.

I feel different from two years ago, I'm more scared...now after Brexit I have the feeling that people don't like you anymore because you are European and they have voted Brexit and they think you are an idiot because you are an immigrant, I'm scared that without knowing who you are if I'm talking with my mom in Italian they will start shouting at us.

Emerging literature on the effects of Brexit is starting to document how Brexit is affecting the sense of security of many migrants (Guma and Jones 2018, Rzepnikowska 2019, Miller 2018, Lulle et al. 2018). Such studies have focused particularly on those in already vulnerable positions who fear loosing their already precarious rights. Here we see that this anxiety extends to established EU migrants including to their 'British' children who are in legally and economically secure positions.

\section{Articulating alternative narratives of belonging}

While being confronted by the power of the "either/or discourse" hardened by the Brexit vote, the children also articulated alternative narratives of home and belonging that often transcended the above dichotomy. Their transnational life-style has resulted in feeling at home in many places, easily adjusting to different environments. These children reflected that their familiarity with different languages and cultures made them more able to understand different cultures. This is evident also in their practices. A number of interviewees had friends that have migrant backgrounds. Hugo (age 15) describes his friends as being "from many different places but they have these foreign parents in common. They all speak two languages; they all understand what is like to be multilingual". Anna too has many international friends; her best friends are from Turkey, Albania, Ukraine and Poland. When asked where she sees herself in the future, she replied that she "wouldn't like to be in the UK but it would probably be in the UK". She would like to be able to leave the UK too "because I'm not very attached to it". Should she end up staying in the UK, she would like it to be in a big multicultural city "where 
they are not all English, where there are also different people" (Anna, 14). In her case, she seems to have embraced her parents' post-national values.

Some children also described their schools as sites of belonging. Both Bob and his brother mentioned their school as a place where everybody was against Brexit. They mention the mock referendums conducted there where $80-90 \%$ voted to stay. Camilla says that she likes to be different at school by talking another language as well as English. When asked what her friends think about it, she says "they think it's cool". She adds that they are used to it as there are other foreign kids at her school (Polish, French, Spanish..) "so it's not unique, but it's not normal I'd say".

While recognizing school and friendship groups as sites of belonging, othering processes occurred there too. Differently to Polish children, Italian children did not receive name-calling (Guma 2018). However, markers of difference where sized upon to "remind" them of their otherness. Bob, for instance, just after the referendum, was told by a schoolmate in an apparently friendly tone "I'm sorry that you have to go to study in Germany now because you are not able to study here anymore”. Even if Bob explained that that was not the case, this boy insisted, repeating this several times. Paolo's "right to be there" was also questioned when a few months after the referendum (but when the UK was still in the EU) was told that his Italian passport was not valid as a proof of age for playing in his local football team, as "foreign" payers were not allowed to play in local leagues without approval. He was eventually allowed to play once his UK birth certificate was produced. The children's whiteness was also at times questioned. Paolo, given his curly hair and olive skin, was asked if he was mixed race, adding to another incident when a child told him that there are three races 'black, white and Italian'. Asked to elaborate, Polo’s younger brother replied, “in-between, neither black nor white”.

Given their own experiences, the children were also very aware of wider discourses on foreigners, which they clearly reject. Fabrizio, talking in 2015 when he was only nine said: 
One thing I can say is that I hate Nigel whatever his name is. Why? He wants to stop foreigners from coming to England so that means mom, everyone out of the question! And.... I'm not so keen on David Cameron either because he doesn't want foreigners to be helped that go to hospital (...).

In the more recent post-Brexit context both Camilla and Anna were very critical of the heightened intolerance towards difference and migrants that has come to dominate the referendum aftermath.

I feel like pushing people out of somewhere where they feel so comfortable (...) it is not $\mathrm{OK}$ to be pushing people out just because they are different. We are going back in time with racism, with things like that, just where you come from and that's not OK. I thought we had got past this. It is just another way to show that England is going back in time (Camilla, 13).

They [foreigners] are always those who are wrong. English people never. Also those not white, terrorists are always Muslim. The terrorist in London was a Muslim who was born in the UK and British, it shouldn't matter that his skin is darker, and obviously Italians, is not that they are that different, aren't they? But when I say that I'm Italian they always say: "Ha so you just eat pizza? You just eat pasta?" So you always say: "mamma mia pizzeria”? Well sorry no. They don't understand anything and they vote to kick them all out, yes like rubbish, sorry (Anna, 14).

As we can see some children have developed transcultural competencies and multicultural and post-national values. However, they have to learn to navigate new racializing processes where they can easily become othered.

\section{CONCLUSIONS}

This article contributes to ongoing debates on integration, identification, home and belonging, and suggests paying more attention to the role of public discourse in shaping these processes. Our analysis went beyond the prevailing rootedness vs. transnational understanding of identity and belonging to focus on new forms of settlement that we have described as transnational emplacement. Although these forms of settlement and 
integration can be seen as successful, they also appear fragile. In fact, we found that the current neo-assimilationist and nationalist political climate in Britain, exacerbated by Brexit, is profoundly affecting EU families and their children.

As the emerging literature on the effects of Brexit on various groups of migrants has started to show (Lulle et al 2018, Guma and Jones 2018, Ranta 2018, Rzepnikowska 2019) for the free-mover parents, Brexit resulted in a loss of security and sense of control over their lives, which affects their wellbeing as well as their current home-making practices. The parents we interviewed had chosen the UK as their home, several stating its distinctive and now disappearing multiculturalist and pluralist stance as a pull factor, and were busy investing in a variety of home-making practices when the Brexit campaign started. The subsequent referendum outcome has undermined their sense of home and belonging, leading to feelings of disembedding (Ryan 2017) and displacement and often regret and resentment for the choices made. This confirms the importance of considering the influence of the structural and discursive context rather than assuming that integration is a linear process that occurs by default with the passage of time (Miller 2018).

Less documented in the literature is the fact that Brexit can represent a moment of crisis for the children too. Despite the familiarity they have with the UK - in many cases their country of birth - children too feel increasingly insecure and fearful both about their future and about how people might see and react to them. Contrary to the early experiences of their parents in the UK, the context in which they grew up has been characterized by rejection of multiculturalism and by renewed nationalism. Political elites have explicitly attacked post-national and plural possibilities of national identification and belonging, re-introducing a sharp binary either/or discourse for electoral success and to facilitate the governance of an increasingly unequal society whose cohesion has allegedly been undermined by outsiders (Però 2013).

This article found that the first generation of children who have lived very transnational lives are very skilled at negotiating belonging in different social and familial settings. They know how to present themselves in a variety of contexts to 
maximize the chances to feel accepted and included. We have also documented the diverse strategies they employ in their everyday life, ranging from internalizing the either/or discourse to leading parallel lives in the private and public spheres. Our article has also shown that, despite children's considerable agency, their choices are limited. Identities are negotiable and fluid up to a point - an Italian cannot suddenly claim to be Japanese, as one of our participants pointed out. One's context shapes the possibilities of identification and belonging. Particularly, public discourses have concrete implications: on the one hand demanding increasing assimilation, while on the other hand simultaneously and hypocritically subjecting the same people to subtle processes of exclusion. The article highlighted the power of the resurrected either/or neo-nationalist discourse and way of thinking in Europe, which the majority of our participants have internalized. Children can choose to be British or Italian (with a growing pressure for the former), but it is increasingly difficult for them to claim dual, multiple or post-national identities in Britain, despite their very transnational and mobile experiences and upbringing. After all, nobody wants to be labelled a "citizen from nowhere", a type of labelling that at once inferiorizes, delegitimizes and excludes.

Brexit emerged as a painful moment of crisis for these children and their families, forcing complex negotiations and decisions on them and triggering processes of emotional detachment from the country where they have grown up. They are made to ask themselves on a regular basis (by the radio, friends, family, school and so on), "Who am I? Where do I come from? Am I white? Will my family be allowed to stay?" In the current neo-assimilationist climate, these children have been made into the vulnerable recipients of such discourses. Paradoxically, the children of so-called denationalized subjects - or aspiring "citizens of the world" - are forced to navigate not only processes of emplacement but also contradictory processes of assimilation and exclusion.

New research is starting to highlight how Brexit others EU migrants in different ways revealing hierarchies of inclusion and exclusion. Although these children could be seen as located in a relatively privileged position within these hierarchies, this study shows how boundaries between "us" and "them" can easily be redrawn and how 
increasingly "to hold British citizenship, to have lived in the UK for a long time, or to be born in the UK were not enough to belong to the UK" (Duru et al 2017).

As we write, very little is known about the "settled status" policy currently being developed by the UK government to determine the legal status of EU nationals living in the UK (UK Government, 2017). For instance, nothing has been said about how it would affect EU children. What can be inferred from reading the document is that potentially EU children who have lived in the UK all their lives would now "need to obtain an immigration status in UK law", thus firmly framing them as "others" by placing them both legally and discursively firmly in the category of "immigrants", with the exclusionary consequences that this entails for their sense of identity and belonging at such a formative time in their lives.

\section{ACKNOWLEDGEMENTS}

We wish to thank the editors of this special issue, Manolis Pratsinakis and Russell King, as well as Elena Genova and the anonymous reviewers for their insightful comments and suggestions. We are also grateful to all the young people and their families who have participated in this research.

\section{REFERENCES}

Barbulescu, R. 2016 "From international migration to freedom of movement and back?", in Lafleur, JM. and Stanek, M., eds. South-North Migration of EU Citizens in Times of Crisis, IMISCOE research series, Springer, 15-31

Billig, M. 1995 Banal Nationalism, Sage, London

Boccagni, P. and Baldassar, L., 2015 "Emotions on the move: mapping the emergent field of emotion and migration", Emotion, Space and Society, 16: 73-80

Bygnes, S. and Erdal, M.B., 2017 "Liquid migration, grounded lives: considerations about future mobility and settlement among Polish and Spanish migrants in Norway", Journal of Ethnic and Migration Studies, 43(1): 102-118 
D'Angelo, A. and Kofman, E. 2016 "Large-scale European migration and the challenge to EU free movement", in Lafleur, JM. and Stanek, M., eds. South-North Migration of EU Citizens in Times of Crisis, IMISCOE research series, Springer, 175-192

D'Angelo, A. and Kofman, E., 2018. From mobile workers to fellow citizens and back again? The future status of EU citizens in the UK. Social Policy and Society, 17(2), pp.331-343

Dubucs, H., Pfirsch, T., Recchi, E. and Schmoll, C., 2017 "Je suis un Italien de Paris: Italian migrants' incorporation in a European capital city", Journal of Ethnic and Migration Studies, 43(4): 578-595

Duru, D.N., Hanquinet, L. and Cesur, N.S., 2017 "Perceptions of diversity and attitudes of tolerance in the "fragmented'UK", Journal of Ethnic and Migration Studies, 43(4): $674-692$

Engbersen, G., and E. Snel. 2013 "Liquid migration: dynamic and fluid patterns of postaccession migration flows", in B. Glorius, I. Grabowska-Lusińska, and A. Kuvik Mobility in Transition: Migration Patterns after EU Enlargement, Amsterdam University Press, Amsterdam, 21-40

Faist, T., 2013 "The mobility turn: a new paradigm for the social sciences?" Ethnic and Racial Studies, 36(11): 1637-1646

Favell, A. 2008 Eurostarts and Eurocities. Free Movement and Mobility in an Integrating Europe, Blackwell, Oxford

Fox, J.E., Moroşanu, L. and Szilassy, E. 2015 "Denying discrimination: status, 'race', and the whitening of Britain's new Europeans", Journal of Ethnic and Migration Studies, 41(5): 729-748

Ghorashi, H. 2017 "Negotiating belonging beyond rootedness: unsettling the sedentary bias in the Dutch culturalist discourse", Ethnic and Racial Studies, 40(14): 2426-2443

Goodhart, D. 2017 The Road to Somewhere. The Populist Revolt and the Future of Politics, Hurst, London

Guma, T., 2018 "Turning citizens into immigrants: state practices of welfare 'cancellations' and document retention among EU nationals living in Glasgow", Journal of Ethnic and Migration Studies: 1-17

Haikkola, L. 2011 "Making connections: Second-generation children and the transnational field of relations", Journal of Ethnic and Migration Studies, 37(8): 12011217

Kilkey, M., 2017 "Conditioning family-life at the intersection of migration and welfare: the implications for 'Brexit families", Journal of Social Policy, 46(4): 797-814 
Kofman, E. 2017 "Brexit families: implications for family life and transnational mobility", Paper Presented at the University of Sheffield, 1 March 2017.

Kundnani, A., 2007 The End of Tolerance. Racism in 21st Century Britain, Pluto, London

Lafleur, J.M. and Mescoli, E. 2018 "Creating undocumented EU migrants through welfare: a conceptualization of undeserving and precarious citizenship",

Sociology, 52(3): 480-496

Lulle, A., Moroşanu, L. and King, R., 2018 "And then came Brexit: Experiences and future plans of young EU migrants in the London region", Population, Space and Place, 24(1)

Lulle, A., King, R., Dvorakova, V. and Szkudlarek, A. 2018 "Between disruptions and connections: "new" EU migrants in the UK before and after the Brexit", Population, Space and Place

McGhee, D., Moreh, C. and Vlachantoni, A. 2017 “An 'undeliberate determinacy'? The changing migration strategies of Polish migrants in the UK in times of Brexit", Journal of Ethnic and Migration Studies, 43(13): 2109-2130

Marchese, F. 2016 "Could UK's Italians rock referendum vote?", BBC News http://www.bbc.co.uk/news/world-europe-38067343 (retrieved 2/2/2018)

Marcu, S., 2014 "Mobility and identity in a wider European Union: experiences of Romanian migrants in Spain", European Societies, 16(1): 136-156

Miller, R.G. 2018 “(Un) settling home during the Brexit process”, Population, Space and Place

Modood, T., 2012 Still Not Easy Being British: Struggles For a Multicultural Citizenship, Trentham Books, Nottingham

Moroşanu, L, and Fox, J. 2013 "'No smoke without fire': Strategies of coping with stigmatised migrant identities.", Ethnicities 13(4) 438-456

Moskal, M. 2015 "When I think home I think family here and there': Translocal and social ideas of home in narratives of migrant children and young people" Geoforum, 58: 143-152

Però, D. 2013 "Migrants, cohesion and the cultural politics of the state: critical perspectives on the management of diversity", Journal of Ethnic and Migration Studies, 39(8): 1241-1259. 
Pratsinakis, M., 2018 "Established and outsider nationals: Immigrant-native relations and the everyday politics of national belonging", Ethnicities, 18(1): 3-22

Ranta, R. and Nancheva, N. 2018 'Unsettled: Brexit and European Union nationals' sense of belonging", Population, Space and Place

Reynolds, T. and Zontini, E. 2016 "Transnational and diasporic youth identities: Exploring conceptual themes and future research agendas", Identities, 23(4): 379-391.

Recchi, E., 2015. Mobile Europe: The theory and practice of free movement in the EU. Springer

Ryan, L. 2018 "Differentiated embedding: Polish migrants in London negotiating belonging over time", Journal of Ethnic and Migration Studies, 44(2), pp.233-251

Ryan, L. and Mulholland, J., 2014 "Trading places: French highly skilled migrants negotiating mobility and emplacement in London", Journal of Ethnic and Migration Studies, 40(4): 584-600

Rzepnikowska, A. 2019 "Racism and xenophobia experienced by Polish migrants in the UK before and after Brexit vote", Journal of Ethnic and Migration Studies, 45(1): 61-77

Seeberg, M.L. and Gozdziak, E.M. eds. 2016 Contested Childhoods: Growing Up in Migrancy: Migration, Governance, Identities. Springer

Svašek, M., 2008 "Who cares? Families and feelings in movement", Journal of Intercultural Studies, 29(3): 213-230

Svašek, M., 2010 "On the move: Emotions and human mobility”, Journal of Ethnic and Migration Studies, 36(6): 865-880

UK Government 2017 The United Kingdom's exit from the European Union: safeguarding the position of EU citizens living in the UK and UK nationals living in the EU, Policy Paper

van Liempt, I. 2011 "Young Dutch Somalis in the UK: citizenship, identities and belonging in a transnational triangle", Mobilities, 6(4): 569-583

Vertovec, S. and Wessendorf, S. 2010 The Multiculturalism Backlash: European Discourses, Policies and Practices, London: Routledge

Virdee, S. and McGeever, B. 2017 "Racism, crisis, Brexit", Ethnic and Racial Studies, 41(10): 1802-1819

Weller, S., 2012 "Evolving creativity in qualitative longitudinal research with children and teenagers", International Journal of Social Research Methodology, 15(2): 119-133 
Zontini, E., 2015 "Growing old in a transnational social field: Belonging, mobility and identity among Italian migrants”, Ethnic and Racial Studies, 38(2): 326-341.

Zontini, E. and Reynolds, T. 2018 'Mapping the role of 'transnational family habitus' in the lives of young people and children”, Global Networks, 18(3): 418-436.

${ }^{i}$ EU children here refer to children born in the UK and elsewhere to at least one Italian parent. The majority of children were EU resident foreign nationals at the time of interview; a minority were British citizens due to having a British parent. 